\title{
New Approach for Controlling Broomrape Plants in Faba Bean
}

\author{
Kandil, E. E. E. ${ }^{1}$; A. M. Kordy ${ }^{1}$; and A. A. Abou Zied ${ }^{2}$
}

\begin{abstract}
To improve controlling Broomrape (Orobanche crenata) grown in faba bean crop via new approaches as planting modern cultivars under different times of spraying Roundup ${ }^{\circledR}$ ((glyphosate $48 \%$ WSC)) as herbicide and foliar application of some micronutrients ( $\mathrm{Fe}, \mathrm{Mn}$ and $\mathrm{Zn}$ ), was conducted in a private farm in El-Horreya village, Abou El-Matamir, El-Behira governorate, Egypt, during two successive winter seasons of 2012/2013 and 2013/2014 in sandy loam soil. The experimental design was a split- split plot design with three replications, where as the treatments were distributed at random as follows; Roundup $^{\circledR}$ (glyphosate) spraying times (without, one time, or two times) were applied at main plots, while foliar spray of micronutrients ( $\mathrm{Fe}, \mathrm{Mn}$ and $\mathrm{Zn}$ ) were allocated in the subplots and field bean cultivars (Nubaria1, Nubaria 2 or Nubaria 3) were located in the sub-sub plot. The main results indicated that spraying Roundup ${ }^{\circledR}$ (glyphosate $48 \%$ WSC) twice where, the first spraying applied beginning the flowering while the second spraying was applied after two weeks from the first treatment at $180 \mathrm{~cm}^{3}$ (Roundup)/480 L (water)/ha.), caused significant increase of faba bean yield and reduced number and weight of broomrape as compared with other treatments. "Nubaria 2" cultivar achieved the highest mean values for most of yield characters, while the cultivar Nubaria 3 gave the lowest values. On the other hand, spraying micronutrients 2 times after 45 and 60 days from sowing achieved higher yield and its components of faba bean under the study condition in El-Behira Governorate, Egypt.
\end{abstract}

Keywords: Faba bean cultivars; broomrape; yield components; herbicides; micronutrients; glyphosate; Roundup

\section{INTRODUCTION}

Faba bean (Vicia faba L.) is a major food and feed legume because of its high nutritional value of the seeds. It is considered one of the most important legumes in Egypt. It has become one of the strategic crops due to its income to the farmers. Also, its important for soil fertility, human nutrition as a good source of vegetarian protein animal feeding and industry purposes (Sharaan et al., 2004). Increasing faba bean production and improving yield quality is the major target to meet the demand of the increasing population, since faba bean constitutes a major part of the diet of people (Zeidan, 2002).

\footnotetext{
${ }^{1}$ Plant production Department, The Faculty of Agriculture

Saba Basha, Alexandria University, Egypt..

${ }^{2}$ Legumes Crops Department, Field Crops Institute,

Agric. Res. Center (ARC), Egypt.

Received August 2, 2015, Accepted September 30, 2015
}

Egyptian broomrape (Orobanche aegyptiaca Pers.) is an achlorophyllous, phanerogamic holoparasite that attacks the roots of many dicotyledonous crops. It obtains carbon, nutrients, and water through haustoria which connect the parasite to the host vascular system. Broomrape infestations cause extensive reduction in crop yield, adversely affect crop quality, and result in loss of cropping alternatives in infested fields.

Orobanche spp. which belong to the family Orobanchaceae are obligate parasitic flowering plants. The main center of distribution is the Mediterranean basin, where large areas are heavily infested. Yield losses due to Orobanche range from 5 to $100 \%$ depending on the region and the crop. Orobanche species infesting faba bean in the eastern Mediterranean region of Egypt are: O. crenata and O. aegyptiaca / O. ramosa. Production of several important crops (lentil, faba bean, tomato, potato, sunflower, etc.) is threatened by broomrapes (Orobanche spp.). As a result of this threat, the cultivated crop areas infected with broomrapes have been declining steadily in some countries as farmers kept abandoning the production of these crops in heavily infested fields (Bülbül, et al., 2009). In highly infested areas, farmers generally avoid growing faba bean or other susceptible crops, resulting in substantial reductions to both the extent of cultivable areas and to food legume production (Besufikad et al.1999).However, Broomrapes are weedy root parasites that represent a major constraint for faba bean (Vicia faba) cultivation in the Mediterranean area. Control methods are being developed that comprise techniques ranging from agronomical practices to precision farming, including chemical and biological control, genetic and induced resistance, modeling, and probably nanotechnology in a nearby future. However, the main concern is that to date, no single method of control provides complete protection against these parasites. For that reason, an integrated approach is needed in which a variety of such techniques are combined, in order to maintain parasite populations below threshold levels of damage (Pérez-de-Luque et al., 2010). Based upon number of strategies for rootparasitic weed control have been developed including cultural practices and biological and chemical control 
(Joel et al. 2007; Rubiales et al. 2009; FernándezAparicio et al., 2011).

It is well- known that $\mathrm{Mn}, \mathrm{Fe}$, and $\mathrm{Zn}$ are known to be required for all higher plants (Welch, 1995). These elements have been well documented to be involved in photosynthesis, N-fixation, respiration and other biochemical pathways (Marschner, 1986; Marschner et al., 2005). Most of micronutrients, for example Fe and $\mathrm{Mn}$ are readily fixed in soil having alkaline $\mathrm{pH}$. Plant roots are unable to absorb these nutrients adequately from dry topsoil (Graham et al., 1992 and Foth and Ellis, 1996). Magnesium and $\mathrm{Mn}$ are not easily translocated to leaves within the plant system (Foth and Ellis, 1996). Thus, the application of macro- and micronutrients in the cultivation zone may not be meeting the crop requirement for root growth and nutrient use. The alternative approach is to apply these micronutrients as foliar sprays. Foliar spray of different micronutrients has been equally or more effective as soil application by different researchers and foliar spray could be used effectively to overcome the problem of micronutrients deficiency in subsoil (Grewal et al., 1997).

The management of broomrape is often difficult due to its close association with the host for all of its life cycle. Despite many management strategies tried against broomrape (reviewed by Foy et al. 1989; Parker and Riches 1993; Sauerborn 1991), few methods have been reliable and economical, except for use in highvalue crops.

The evaluation of tolerant materials under Orobanche -infested and Orobanche-free fields was investigated by Darwish et al. (1999) Abdalla and Darwish (2002), Morsy and Attia, (2002), Darwish et al. (2007) and Abdalla and Darwish (2008). The above mentioned authors concluded that there were significant differences among genotypes for most studied traits.

Genotypes differed in the level of resistance and seed yield. The average yield for most of the resistant genotypes was two to three folds higher than the local and susceptible. Thus, the highest mean yield and relatively lowest Orobanche infestation was obtained from entries ILB4358, Sel.F5/3053/2003-3, and Sel.F5/3382/2003-4 as compared with others (local and susceptible ones) with highest broomrape infestation. The resistant genotypes seemed to show late Orobanche establishment which gave advantage over the parasite. Using these resistant genotypes the dietary requirement of the population and the nutrient depletion of the area could be fulfilled as they are using cereal-based cropping system due to the invasiveness of the weed. Meanwhile, these entries should be promoted for production and utilization of their desirable gene(s) for further research program and can form appropriate material for an integrated control package (Teferi et al., 2013).

The objectives of the present investigation were; (a) to select a proper faba bean cultivar from the tested modern three cultivars, (b) to determine the adequate number of times of foliar spray of micronutrients and (c) to select appropriate number of times of glyphosate (Roundup) spray and (d) the interaction among these factors, to achieve high yield and controlling broomrape (Orobanche crenata).

\section{MATERIALS AND METHODS}

Two field experiments were carried out to test and achieve the above mentioned objectives using the three modern cultivars of faba bean (Nubaria1, Nubaria 2 or Nubaria 3) in a private farm at El-Horreya village, Abou El-Matamir, El-Behira governorate, Egypt, during two successive winter seasons of 2012/2013 and 2013/2014. The mechanical and chemical analyses of the experimental site are presented in (Table, 1) according to Page et al., (1982).

The experimental design was split- split plot design with three replications and the treatments were distributed at random as follows; Roundup ${ }^{\circledR}$ (glyphosate $48 \%$ WSC) ( $N$-(phosphonomethyl)glycine) spraying times were applied at main plot (without, once and twice time(s) ) beginning the flowering broomrape and after 2 weeks from the first application at $180 \mathrm{~cm}^{3}$ (Roundup)/480 L (water)/ha.), while foliar spray of three micronutrients (Fe, $\mathrm{Mn}$ and $\mathrm{Zn}$ ) as once and twice time(s) spray at rate $480 \mathrm{~g} / \mathrm{ha}$., for each spray were in subplot, and faba bean cultivars (Nubaria1, Nubaria 2 or Nubaria 3) were located in sub-sub plot. The sub plots consisted of 5 ridges 3.5 meters in length, $60 \mathrm{~cm}$ in width and $20 \mathrm{~cm}$ between hills. Faba bean seed treated with Rhizobium inoculation ( $\mathrm{R}$. leguminosum cv. Vicieae bacterium) suspension containing 10 cell bacterium per one gram. However, Nitrogen fertilizer was applied as urea fertilizer $(46 \% \mathrm{~N})$ at the rates $48 \mathrm{~kg}$ $\mathrm{N} /$ ha., as one dose. Phosphorus fertilizer was applied before planting as single Calcium- Super Phosphate $\left(15.5 \mathrm{P}_{2} \mathrm{O}_{5}\right)$ at the rate of $480 \mathrm{~kg} / \mathrm{ha}$. Potassium sulphate $\left(48 \% \mathrm{~K}_{2} \mathrm{O}\right)$, was added before the second irrigation at rate of $120 \mathrm{~kg} / \mathrm{ha}$. Sowing was done on $18^{\text {th }}$ and $20^{\text {th }}$ of October in 2013 and 2014 seasons, respectively. The preceding crop was maize (Zea mays, L.) during both seasons of the study.

Glyphosate [N-(phosphonomethyl)glycine] is a systemic, nonselective, and foliar applied herbicide. It is readily translocated to underground parts, immature leaves, and meristems. It has been reported to be very stable in plants (Coupland 1984; Devine and Bandeen 1983; Gottrup et al. 1976). 
Table 1. Physical and chemical properties of the experimental soil sites during the two cropping seasons (2012/2013 and 2013/2014)

\section{Soil characteristics}

\begin{tabular}{|c|c|c|}
\hline & \multicolumn{2}{|c|}{ Seasons } \\
\hline & 2013 & 2014 \\
\hline Soil texture $(\%)$ & Sandy loam & Sandy loam \\
\hline Sand $\%$ & 60.10 & 62.30 \\
\hline Silt \% & 10.60 & 11.50 \\
\hline Clay \% & 29.30 & 26.20 \\
\hline $\mathrm{pH}(1: 2.5$ water suspension) & 8.10 & 7.99 \\
\hline $\mathrm{EC}\left(\mathrm{dSm}^{-1}\right)$ & 2.10 & 1.95 \\
\hline \multicolumn{3}{|l|}{ Cations (meq/L.) } \\
\hline $\mathrm{Ca}^{++}$ & 7.60 & 9.10 \\
\hline $\mathrm{Mg}^{++}$ & 5.20 & 4.85 \\
\hline $\mathrm{Na}^{+}$ & 4.10 & 4.00 \\
\hline $\mathrm{K}^{+}$ & 0.20 & 0.25 \\
\hline \multicolumn{3}{|l|}{ Anions (meq/L.) } \\
\hline $\mathrm{HCO}_{3}^{-}$ & 2.00 & 1.95 \\
\hline $\mathrm{Cl}^{-}$ & 3.85 & 3.77 \\
\hline $\mathrm{SO}^{--}$ & 10.50 & 12.20 \\
\hline O.M. (\%) & 1.85 & 1.90 \\
\hline $\mathrm{CaCO}_{3}(\%)$ & 22.50 & 23.70 \\
\hline Available Mineral N(mg/kg) & 92.40 & 85.60 \\
\hline Available P (mg/kg) & 23.12 & 25.50 \\
\hline $\begin{array}{l}\text { Its mode of action is the inhibition of the enzyme 5- } \\
\text { enolpyruvylshikimate-3-phosphate (EPSP) synthase that } \\
\text { leads to the production of the aromatic amino acids, } \\
\text { phenylalanine, tyrosine, and tryptophan. } \\
\text { CHARACTERS STUDIED }\end{array}$ & \multicolumn{2}{|c|}{$\begin{array}{l}\text { Spectrophotometer and Flam photometer for N, Fe, } \\
\text { Mn, and } \mathrm{Zn} \text { determination, according to Gericke and } \\
\text { Kurmies (1952). N- values were multiplied by } 6.25 \\
\text { to calculate protein content. }\end{array}$} \\
\hline
\end{tabular}

a) Total chlorophyll content (SPAD value) of faba bean leaves was determined by Minolta Chlorophyll Meter 502. Chlorophyll a was calculated by transforming the SPAD units to $\mathrm{mg} / \mathrm{m}^{2}$ using the following equation: Chlorophyll $=1.034+0.308 \mathrm{x}$ [SPAD $+0.110 *$ [SPAD $^{2}$ according to Monje and Bugbee (1992).

b) At harvest in both seasons, broomrape samples from one square meter area were randomly collected from each plot. Number and dry weight of broomrape plants $/ \mathrm{m}^{2}$ were determined after drying in a forced draft oven at $70 \mathrm{C}^{0}$ to constant weight.

c) At harvest stage, the following data were recorded: Plant height $(\mathrm{cm})$, Pod length $(\mathrm{cm})$, Number of pods/plant, Number of seeds/plant, 100- seed weight (g), Seed yield (tons/ha), straw yield (tons/ha), biological yield (tons/ha) and harvest index (H.I. \%) was calculated from the weight of seeds obtained from each plot.

d) Faba bean seed samples were dried, grinded, weighted $(0.50 \mathrm{~g})$, burned, made ash solution,
All the data collected were subjected to statistical analysis of variance according to Gomez and Gomez (1984), using CoStat (1998) program.

\section{RESULTS AND DISCUSSION}

The results in Tables (2 and 3) show the significant effect of times spray of roundup, foliar spray of micronutrients and cultivars of faba bean and their interactions on plant height $(\mathrm{cm})$, total chlorophyll, pod length $(\mathrm{cm})$, number of pods/plant, seed yield, straw and biological yields, harvest index (H.I.\%) and seed protein \% during two growing winter seasons. Whereas, the highest mean values from plant height, total chlorophyll $\left(\mathrm{mg} / \mathrm{m}^{2}\right)$, yield and its components of faba bean plants were achieved with spray roundup as herbicide, two times (after 4 and 7 weeks from sowing) and Nubaria 2 with no significant differences different on plant height when spray roundup was sprayed once, while the lowest values from plant height and faba bean leaves content from chlorophyll as recorded with without roundup spray. This could be due to low stimulation of broomrape germination and a delay in orobanche formation and development (Abbes et al., 
2006), and to a deeper root system of the host (Abbes et al., 2007).

Also results in Table, 2 declared that the longest pod, highest number of pods/plant, heaviest 100- seed weight seed yield, straw and biological yields (tons/ha.), harvest index (H.I.\%) and highest concentration of seed protein $\%$ of faba bean was observed due to spraying roundup twice as comparison with other treatments (once and without spray). Similar results, were obtained by Zein et al. (2004) who reported that the application of glyphosate at $86.4 \mathrm{~g}$ a.i./ha., (Two or three times) or Imazethapyer at $72 \mathrm{~g}$ a.i./ha., (soil incorporation) were the most effective treatments against broomrape and produced the highest faba bean yield. This reduction was exaggerated when releasing P. orobanchia was combined with glyphosate at $86.4 \mathrm{~g}$ a.i./ha., or with hand pulling (once). Releasing Phytomyza with glyphosate achieved the highest increase in faba bean seed yield.

Foliar sprays twice of micronutrients ( $\mathrm{Fe}, \mathrm{Mn}$ and $\mathrm{Zn})$, led to the highest mean values of plant height $(\mathrm{cm})$, total chlorophyll, pod length $(\mathrm{cm})$, number of pods/plant, seed, straw and biological yields, harvest index (H.I.\%) and seed protein \% as compared with other treatment (spray once) during both seasons. It is clear the faba bean yield was increased and its components in the productivity of faba bean plants as results of micronutrients might have increased photosynthesis activity and consequently produced more metabolites required for building up the growing pods (Abdel Monem et al. 2009).

These results were in agreement with those obtained by Grewal et al. (1997) who revealed that dry matter production increase with application of micronutrients over control. Also, Sadana et al. (2002) indicated that increase dry matter yield with Mn application.

Regarding the effect of faba bean cultivars, the obtained results that there were significant differences among three cultivars, where, the cultivar Nubaria 2 gave the highest mean values of plant height $(\mathrm{cm})$, total chlorophyll, pod length $(\mathrm{cm})$, number of pods/plant, seed, straw and biological yields, harvest index (H.I.\%) and seed protein \%. While the "Nubaria 1 " cv., recorded the lowest ones during both seasons.

The interactions effect between "Roundup $\mathrm{x}$ Micronutrients", "Roundup x cultivars", "Micronutrients X cultivars" and "Roundup X Micronutrients x cultivars" on plant height $(\mathrm{cm})$, total chlorophyll, pod length (cm), number of pods/plant, seed, straw and biological yields, harvest index (H.I.\%) and seed protein \% were mentioned in (Table 2 and 3) during two growing winter seasons.
Data presented in Table (4) indicated that there was significant effect of number of spray times of roundup, foliar spray of micronutrients and three cultivars of faba bean on number and weight of Broomrape $/ \mathrm{m}^{2}$, seed content of $\mathrm{Fe}, \mathrm{Mn}$ and $\mathrm{Zn}(\mathrm{mg} / \mathrm{g}$ ) during the two seasons. Whereas, number and weight of broomrape $/ \mathrm{m}^{2}$ were reduced with spraying of roundup twice as compared with others treatment (No spray and spraying once from roundup) during both seasons.

Abebe et al. (2013) detected that the genotype ILB1814 (susceptible check) was most strongly affected by $O$. crenata, showing the highest broomrape population and the lowest grain yield, despite its high yield potential when not infested. On the other hand, ILB4358, Sel.F5/3382/2003-4 and ILL4338 were less susceptible and may carry some genes rendering them resistant to Orobanche. Also, Abd El-Wahab, 2007 reported that faba bean genotypes differed from each other in their yield and yield components regarding Orobanche infestation.

With the respect of Table, 4 spraying micronutrients twice of ( $\mathrm{Fe}, \mathrm{Mn}$ and $\mathrm{Zn}$ ) gave the lowest number and weight of broomrape $/ \mathrm{m}^{2}$ as compared with other treatment (one spray) during both seasons.

With regard to the faba bean cultivars, "Nubaria 2" cultivar recorded the lowest mean value of number of broomrape $/ \mathrm{m}^{2}$ and lightest weight of broomrape $/ \mathrm{m}^{2}$ in comparison with other field bean cultivars "Nubaria, 3 and 1 ".

There were considerable differences among faba bean genotypes in their response to $\mathrm{O}$. crenata. Generally, differences in infection and seed yield among the seasons can be attributed to variations in weather conditions, which are known to influence both the extent of Orobanche infestation and faba bean growth (Rubiales et al., 2006). Also, they inducted that several criteria have been used by the authors to quantify resistance to Orobanche infestation, such as: number of Orobanche per host plant; dry matter of parasitic plants per host plant; height of the tallest parasitic shoot; number of Orobanche per sown surface unit, etc.

Also, in Table (4) it was observed that the highest mean values of faba bean chemical compassion (Fe, Mn and $\mathrm{Zn}$ ) was observed with spraying roundup twice as compared with other treatments (No spray and once).

Number of foliar sprays times of micronutrients exerted, significantly, on faba bean chemical compassion (Fe, $\mathrm{Mn}$ and $\mathrm{Zn}$ ). However, spraying micronutrients twice gave the highest concentrations of $\mathrm{Fe}, \mathrm{Mn}$ and $\mathrm{Zn}(\mathrm{mg} / \mathrm{g})$ as compared with other treatment (i.e. spraying once) during both growing seasons. 


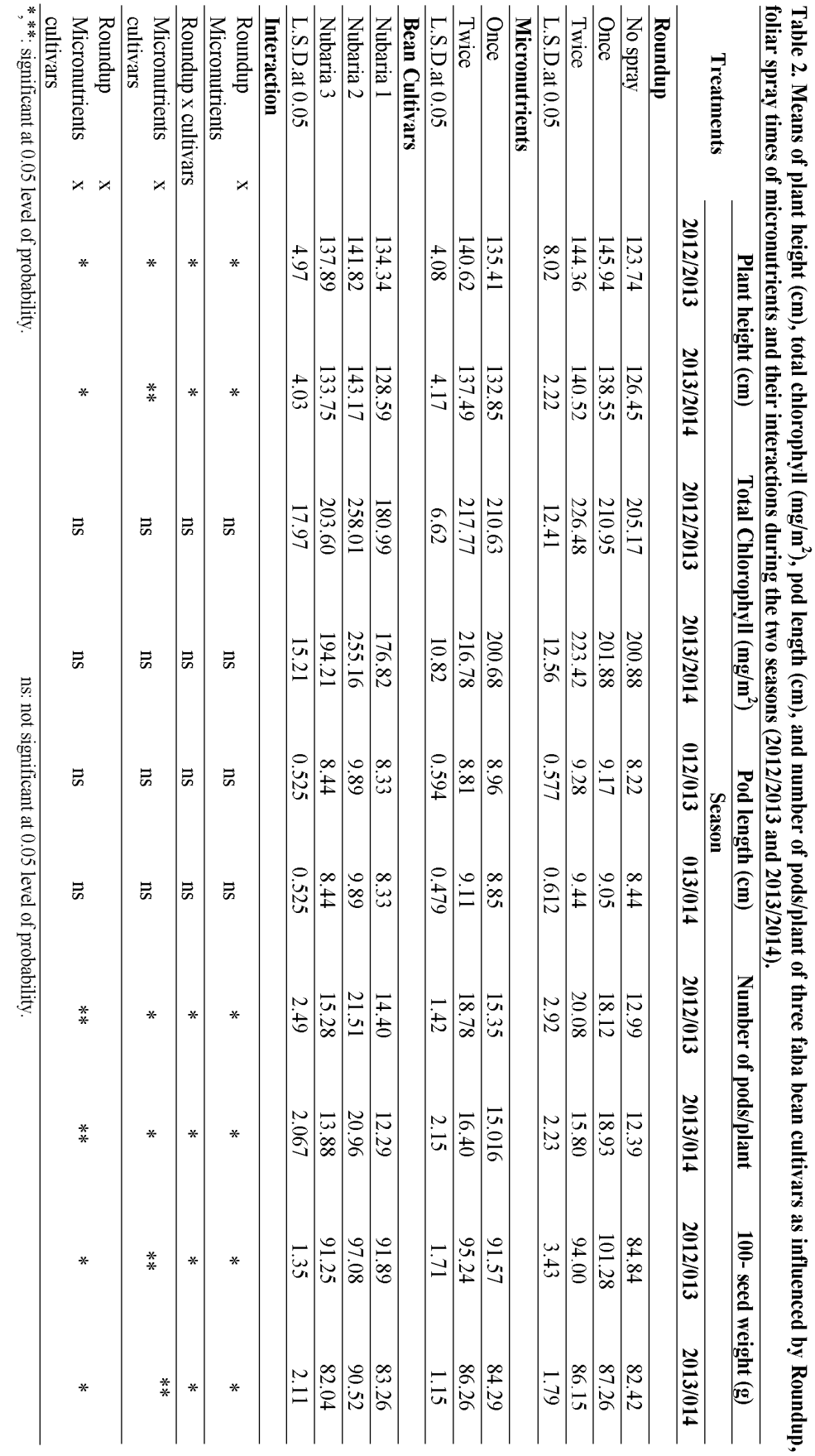




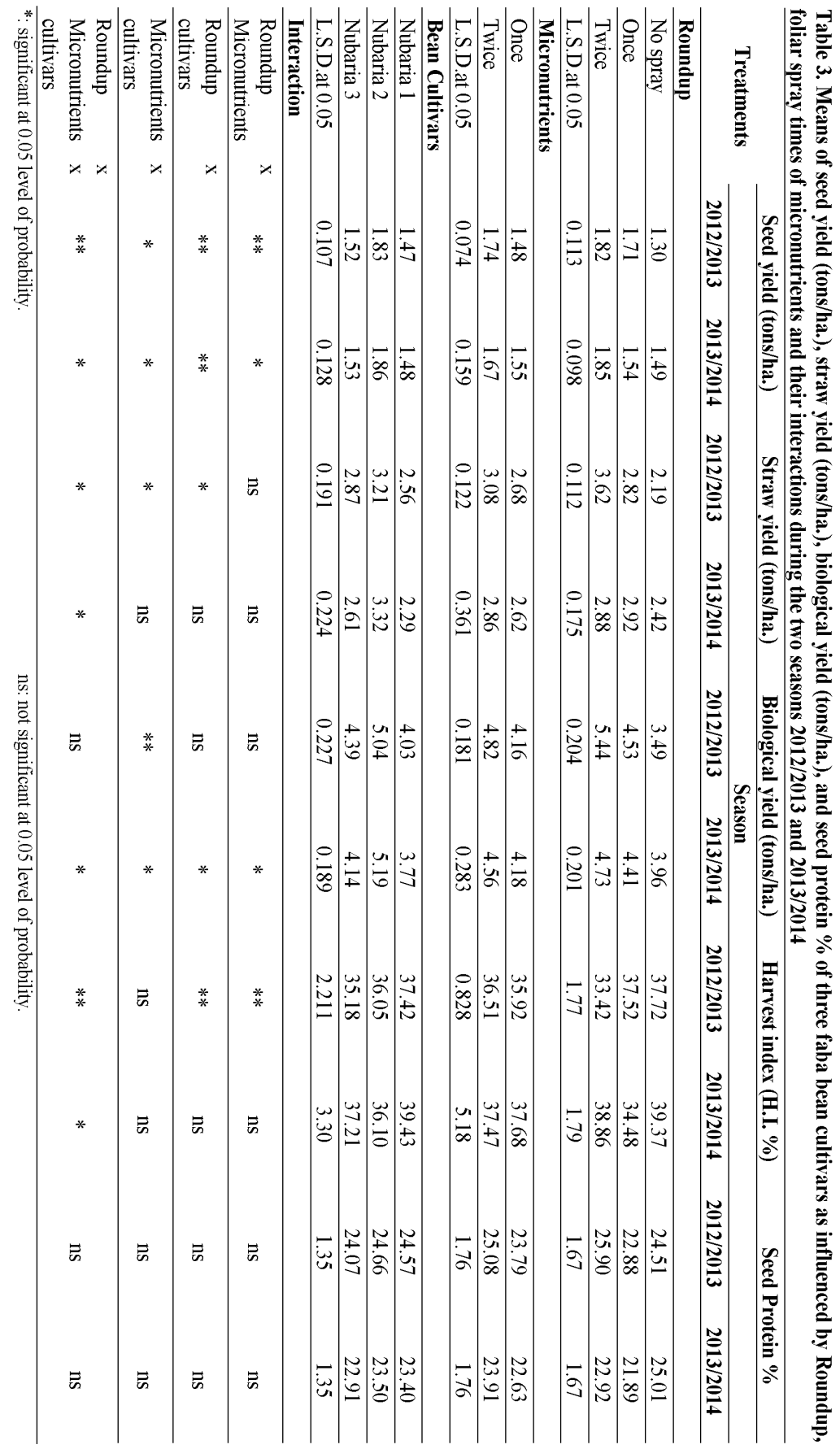




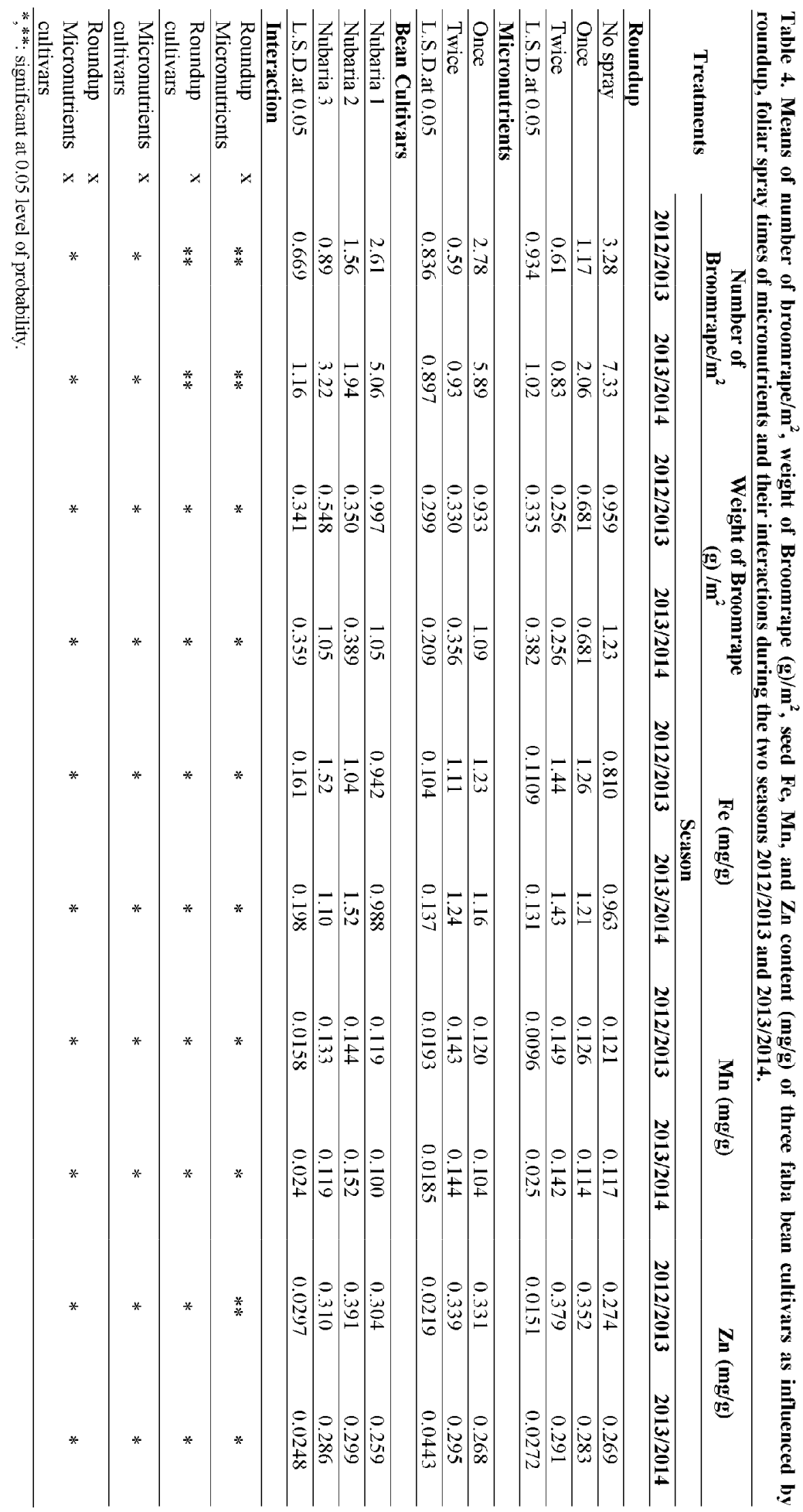


The highest mean values of chemical compassion (Fe, $\mathrm{Mn}$, and $\mathrm{Zn}$ ) were recorded with faba bean cultivar "Nubaria 2". While the lowest ones were achieved by "Nubaria 1" cv. The first and second order interactions between "Roundup x Micronutrients", "Roundup x cultivars", "Micronutrients x cultivars" and among "Roundup X Micronutrients $x$ cultivars" were significant, while they were insignificant during both season or only one season, on number of Broomrape $/ \mathrm{m}^{2}$ , Weight of Broomrape $(\mathrm{g}) / \mathrm{m}^{2}$, seed $\mathrm{Fe}, \mathrm{Mn}$ and $\mathrm{Zn}$ $(\mathrm{mg} / \mathrm{g})$ during the two seasons, presented in Table (4).

Iron is a constituent of many enzymes involved in the nutritional metabolism of plant. Zinc plays an important role as a metal component of enzymes (superoxide dismutase, carbonic anhydrase an polymerase) or as a functional, structural, or regulate RNA cofactor of a large number of enzymes (KabataPendias and Pendias 1999).

Resistance to broomrape appears to have multiple components and to be based on a chain of escape and resistance mechanisms that either act alone or in combination and at different stages of the infection process. The increased efforts in delivering the control by resistant cultivars can be more effectively made, and the tools of modern plant breeding and of heterologous gene transfer (Dita et al. 2006; Rispail et al. 2007; Yoder et al. 2009) will be valuable.

Strategies of Broomrape's control have been developed but only marginal successes have been achieved. Most control methods are unfeasible, uneconomical, and hard to achieve or result in incomplete protection. Breeding for resistance is possible, but it is hampered by the lack of sufficient levels of resistance, the complexity of its inheritance and the unreliability of available screening methods. Recent achievements in the identification of resistance levels and their deployment in breeding programmes will be presented and critically discussed (Rubiales, 2014)

Table (4) showed that there were significant interactions "Roundup x Micronutrients", "Roundup x cultivars", "Micronutrients x cultivars" and "Roundup x Micronutrients x cultivars" on number of broomrape $/ \mathrm{m}^{2}$ , weight of Broomrape $(\mathrm{g}) / \mathrm{m}^{2}$, seed $\mathrm{Fe}, \mathrm{Mn}$, and $\mathrm{Zn}$ content $(\mathrm{mg} / \mathrm{g})$ during the two seasons.

The results of this study will could be used to help the farmers to choose the appropriate cultivar for areas that are infested by $O$. crenata and will form cost effective integrated control package against this ever increasing dreadful weed. Moreover, using these Orobanche resistant genotypes, the dietary requirement of the household could be fulfilled and the nutrient depleted area could be recovered as they are frequently using mono-cropping of cereals due to the invasiveness of $O$. Crenata.

\section{CONCLUSION}

The present study could lead to conclude that for better faba bean yield and its components by planting cultivar "Nubaria 2" cv., with two sprays from Roundup $^{\circledR}$ (Glyphosate) at (4 and 8 weeks from sowing) and two foliar sprays of micronutrients and reduce number and weight Broomrape $/ \mathrm{m}^{2}$ under study conditions at Abou El-Matamir, El-Behira governorate, Egypt.

\section{REFERENCES}

Abbes, Z., M. Kharrat and W. Chaibi, 2006. Study of the interaction between Orobanche foetida and faba bean at root level. Tunisian J. Plant Prot. 1: 55-64.

Abbes, Z., M. Kharrat, P. Simier and W. Chaïbi, 2007. Characterization of resistance to crenate broomrape (Orobanche crenata) in a new small-seeded line of Tunisian faba beans. Phytoprotection 88: 83-92.

Abd El-Wahab M.M.H.2007. Selection for Orobanche tolerance in segregating generations of faba bean. M. Sc. Thesis. Fac. Agric., Cairo university. Egypt.

Abdalla, M.M.F. and D.S. Darwish, 2002. Faba bean breeding in Egypt for tolerance to Orobanche : a review. Egypt. J. Plant Breed. 6 (1): 143-160.

Abdalla, M.M.F. and D.S. Darwish, 2008. Investigations on faba bean, Vicia faba L. 24- Cairo4, Cairo5 and Cairo25 new varieties tolerance to Orobanche. Egypt. J. Plant Breed. 12 (1): 315-320.

Abebe T., K. Meles, Y. Nega, H. Beyene and Abrha Kebede, 2013. Variation in the resistance of some (Vicia faba L) Faba bean genotypes to Orobanche crenata in Tigray, Ethiopia. Direct Res. J. Agric. Food. Sci. 19: 1 (2)18-24.

Besufikad T, B. Legesse and F. Rezene, 1999. Orobanche problem in South Welo. Arem 5:1-10.

Bülbül, F., E.Aksoy, S. Uygur and N. Uygur.2009. Broomrape (Orobanche spp.) Problem in the eastern mediterranean region of Turkey. HELIA, 32: 51, 141-152.

CoStat (1998-2005). 6.4. Cohort software798 light house Ave. PMB320, Monterey, CA93940, and USA.email: info@cohort.com and Website: http://www.cohort.com/DownloadCoStatPart2.html.

Coupland, D. 1984. The effect of temperature on activity and metabolism of glyphosate applied to rhizome fragments of Elymus repens (= Agropyron repens). Pestic. Sci. 15:22634.

Darwish. D., M.M.F Abdalla., M. A. Omar., S.R.E. AboHegazy., and T.S.A. Marsafawy.2007. Investigations on faba bean, Vicia faba L. 21- Inheritance of Orobanche tolerant/ resistance. Fifth Plant Breed., Conf., May, Giza. Egypt. J. plant Breed., 11(1): 953-967 Special lssue. 
Darwish. D., M.M.F Abdalla.,E .A. El- Metwally.,M. H. ElSherbeeny., and Sabah M. Attia (1999). Investigations on faba bean, Vicia faba L.13- performance of some faba bean genotypes and their hybrids under Orobanche infestation. Proceed. First Pl. Breed. Conf. Dec. 4 (Giza).Egypt. J. Plant Breed. 3:231-246.

Devine, M. D., and J. D. Bandeen. 1983. Fate of glyphosate in Agropyron repens (L.) Beauv.growing under low temperature conditions. Weed Res. 23:69-75.

Dita, M.A., N. Rispail, E. Prats, D. Rubiales, and K.B. Singh (2006): Biotechnology approaches to overcome biotic and abiotic stress constraints in legumes. Euphytica, 147: 124.

Fernández-Aparicio, M., J.H.Westwood, and D. Rubiales, 2011. Agronomic, breeding, and biotechnological approaches to parasitic plant management through manipulation of germination stimulant levels in agricultural soils. Botany, 89: 813-826.

Foth, H. D. and B.G. Ellis. 1996. Soil fertility. 2nd Ed. Lewis Pub. New York.

Foy, C. L., R. Jain, and R. Jacobsohn. 1989. Recent approaches for chemical control of broomrape (Orobanche spp.). Rev. Weed Sci. 4:123-52.

Gericke, S. and B. Kurmies. (1952). Die kolorimetrische Phosphorsäurebestimmung mit Ammonium-VanadatMolybdat und ihre Anwendung in der Pflanzenanalyse. Zeitschrift für Düngung, Pflanzenernährung und Bodenkunde 59:235-247.

Gomez, K.A. and E.A. Gomez, 1984. Statistical procedures for agricultural Research. John Wiley and Son. Inc., New York.

Gottrup, O., P. A. O'Sullivan, R. J. Schraa, and W. H. Vanden Born. 1976. Uptake, translocation, metabolism and selectivity of glyphosate in Canada thistle and leafy spurge. Weed Res. 16:197-201

Graham R.D. and Ascher, J. S. 1993. Nutritional limitations of subsoils. In. Plant nutrition- from genetic engineering to field practice. Ed. N T Barrow. pp 739-742, Kluwer Academic Publishers, Dordrecht.

Grewal, H.S., L. Zhonggu and R.D. Graham. 1997. Influence of subsoil zinc on dry matter production, seed yield and distribution of zinc in oilseed rape genotypes differing in zinc efficiency. Plant and Soil. 192(2): 181-189.

Joel D.M., J. Hershenhorn, H. Eizenberg, R. Aly, G. Ejeta, P.J. Rich, J.K. Ransom, J. Sauerborn, and D.Rubiales,2007. Biology and management of weedy root parasites. Horticultural Reviews, 33: 267-349.

Kabata-Pendias, A. And H. Pendias, 1999. Biogeochemistry of Trace Elements. PWN, Warsaw, Poland

Marschner, H. 1986. Mineral nutrition of higher plants. Acad. Press Inc., London.

Marschner, P., Z. Solaiman and Z.Rengel, 2005. Growth, phosphorus uptake, and rhizosphere microbial-community composition of a phosphorus-efficient wheat cultivar in soils differing in pH. J. Plant Nutr. Soil Sci. 168: 343-351.
Monje, O.A. and B. Bugbee, 1992. Inherent limitation of nondestructive chlorophyll meters. A comparison of two types of meters. Hort. Sci., 27: 69-71.

Morsy, M. Somaya and Sabah M. Attia .2002. Effect of Orobanche parasitizm on yield and some technological characters of faba bean. Egypt J. Appl. Sci. 17 (5): 306322.

Page, A.L., R.H. Miller and D.R. Keeney, 1982. Methods of Soil Analysis. II: Chemical and Microbiological Properties, 2nd ed.Am.Soc.Agron.Inc; Soil. Soil Sci Soc. Am.Inc, Madison, Wisconsin U.S.A.

Parker, C. and C. R. Riches. 1993. Parasitic Weeds of the World: Biology and Control.Wallingford, UK:CAB International. $332 \mathrm{p}$.

Pérez-de-Luque A., H. Eizenberg, J. H. Grenz, J. C. Sillero, C. Ávila, J. Sauerborn, and D. Rubiales (2010). Broomrape management in faba bean. Field Crop Res 115:319-328.

Rispail, N., M.A.Dita, C.I.González-Verdejo, A.PérezDeLuque, M.A.Castillejo, E. Prats, B. Román, J. Jorrín and D. Rubiales, 2007: Plant resistance to parasitic plants: molecular approaches to an old foe. New Phytologist, 173: 703-712.

Rubiales D., A. Pérez-de-Luqu, M. Fernandez-Aparicio, J. C. Sillero, B. Roman, M. Kharrat, S. Khalil, D. M. Joel, and C. Riches, 2006. Screening techniques and sources of resistance against parasitic weeds in grain legumes. Euphytica 147: 187-199.

Rubiales D., M. Fernández-Aparicio, K.Wegmann, and D.M. Joel, 2009. Revisiting strategies for reducing the seedbank of Orobanche and Phelipanche spp. Weed Research, 49: 23-33

Rubiales, D., 2014.Legume Breeding for Broomrape Resistance. Czech J. Genet. Plant Breed, 50, 2014 (2): 144-150 (Review).

Sadana, U.S., K. Lata and N. Claassen, 2002. Manganese efficiency of wheat cultivars as related to root growth and internal manganese requirement. Journal of Plant Nutrition 25 (12): 2677 - 268.

Sauerborn, J. (1991) Parasitic Flowering Plants: Ecology and Management. Weikersheim, FRG:Verlag Josef Margraf. $127 \mathrm{p}$.

Sharaan, A.N., A.Ekram, H.A.S.Megawer, and Z.A. Hemida, 2004. Seed yield, yield components and quality character as affected by cultivars, sowing dates and planting distances in faba bean. Bull. Agric. Econ. Min. Agric. Egypt.

Teferi, T. A., K. Meles, Y. Nega, H. Beyene, and A. Kebede, 2013. Interaction between broomrape (Orobanche crenata) and resistance faba bean genotypes (Vicia faba L.) in Tigray region of Ethiopia. Canadian J. Plant Protection (CJPP).1: 3. ISSN 2291-3262 (Online).

Welch R.M., W.H.Allaway, W.A. House, and J. Kubota. 1991. Geographic distribution of trace element problems. In: Mortvedt J.J., ed. Micronutrients in agriculture, 2nd Ed. Madison, Wisconsin: SSSA Book Ser. 4. SSSA. 3157. 
Yoder, J.I., P. Gunathilake, B.Wu, N.Tomilova, and A.A. Tomilov (2009): Engineering host resistance against parasitic weeds with RNA interference. Pest Management Science, 65: 460-466.

Zeidan, M.S., 2002. Effect of sowing dates and urea foliar application on growth and seed yield of determinate faba bean (Vicia faba L.) under Egyptian conditions. Egypt. J. Agron. 24, 93-102.
Zein, A.A., M.M. Abd El-Hamid, M.F.Shady and M.E. Kenapar.2004.Effect of sowing date broomrape (Orobanche crenata Forsk) control and releasing Phytomyza orobanchia, Kalt, on faba bean (Vicia faba L.) growth and productivity. J. Agric. Res. Tanta Univ., 30 (2), 465-486.

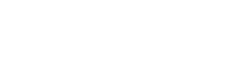

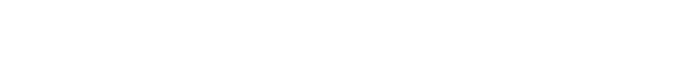

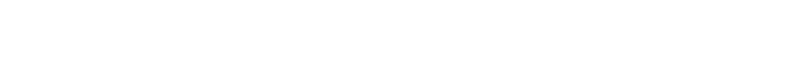

بذرة، محصول البذور ومحصول القث والمحصول البيولوجى ودليل الحصاد\% بوقارنة ببالقى المعلملات

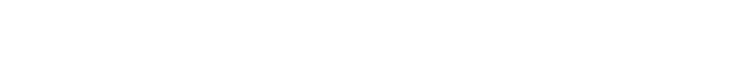

$$
\text { r.r. }
$$

صفات المحصول ومكوناته وتحمله اللهالوك خلاف الأل فن

$$
\text { موسو الزراعة. }
$$

- الرش الورقى للعناصر الصغرى مرتين بمعل (نصف

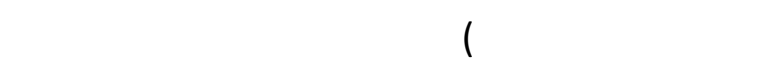
المحصول ومكوناته للفول البلدى خلل الموسمين.

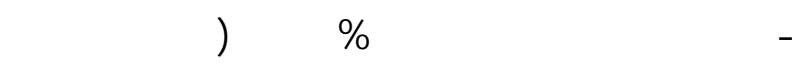

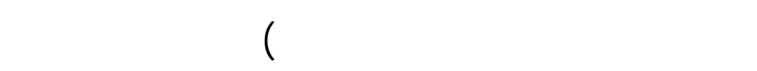

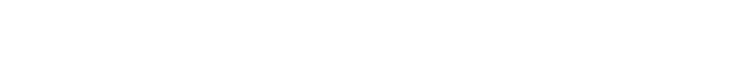
ن الباتلت الهالوك بالمتر المريع.

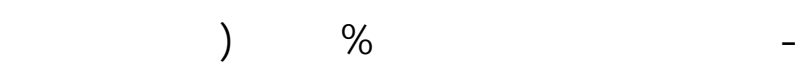
التزهير والأخرى بعدها بلسبوعين) والرش باشبن بالعناصر

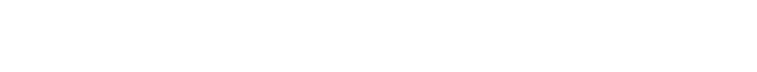
التل قيم لتركيزات العناصر الصغرى خلل الموسمين، واليضاً تاثير التدلخل.

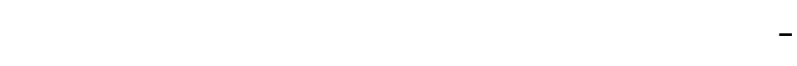
الرولندب والعناصر الصغرى للحصول على التنلجية

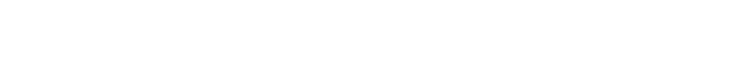
لكثر تمتظروف التجربة بالبحيرة.
أقيمت تجرببتان حقليتلن بمزرعة خاصة بقرية الحرية-

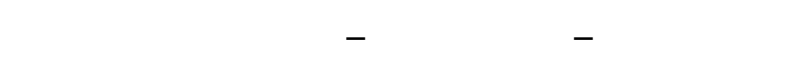

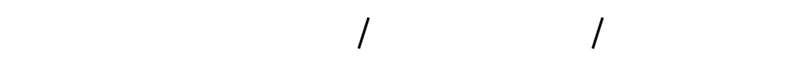

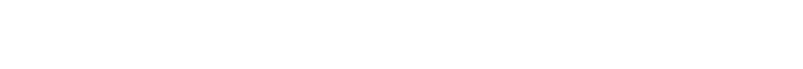

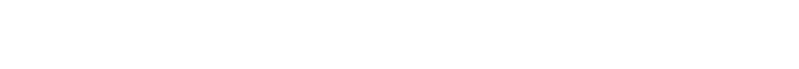

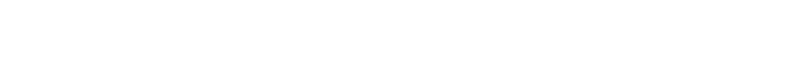

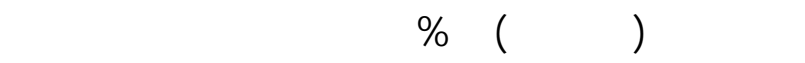
بالعناصر الصغرى مل الحديد والزكك والمنجنيز لانتتاج نباتنات قوية لكثر مقاومة. لمستخم تصميم القطع المثثقة مرتين فى ثلاثة مكرارات

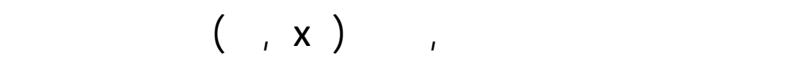

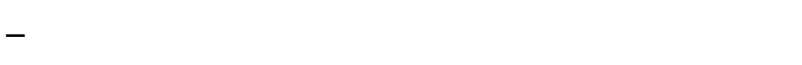
الروالدداب ^ع\%(بدون- الرش مرة ولحة- الرش مرتبن) بالتطع الرئيسية- الرش الراونداب عند بداية التزهير،

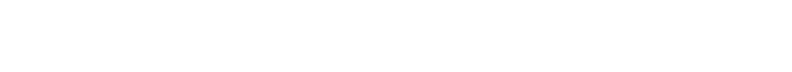
سم"/هكتار، والرش الورقى للعناصر الصغرى(حديد، زيك،

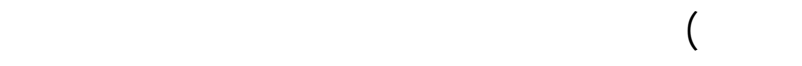
وزرعت ثلالثة أصناف من الفول البلدى (نوبارية ا، نوبارية الفئية

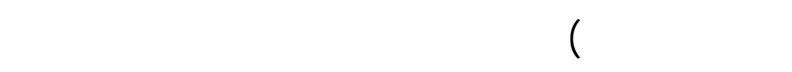

$$
\text { ولخصت أهم النتائج فيما يلم: }
$$

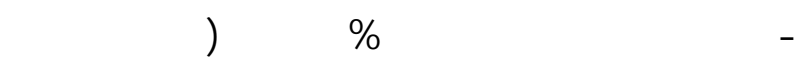

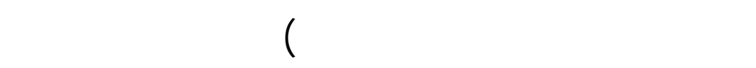
للمحصول ومكونانه مل (إرفاع النبلت، وزن ... 